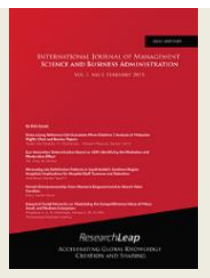

\title{
Analysis and Selection of a Business Model: the Case of Delphi Subway Transportation Project
}

\author{
Nikolaos Papanikolaou \\ National Library of Greece, Stavros Niarchos Foundation Cultural Center, Greece
}

\begin{abstract}
This paper examines the conditions of developing an additional line to the Delhi subway in India, in order to facilitate transportation in the city during the Commonwealth Games. The paper is developed through analyzing the business model that delivered the development of the project, examine advantages, disadvantages, results delivered, and proposes what could have done differently in order to minimize risks. This is a case of public and private sector cooperation.
\end{abstract}

Keywords: Business model, Development, Project, Public - private sector, Transportation.

\section{Introduction}

In India, where the project under consideration is going to be developed (the project that was going to be constructed was related with the conduct of the Commonwealth Games and the connection of the new Delhi Railway Station with the Indira Gandhi International (IGI) Airport through a subway system that would facilitate the city's traffic), public-private partnership was the basic model in constructions, meaning the cooperation of the private sector with the public (Aboubakr, 2013). This model is ideal because of the following reasons (Grimsey, et all, 2005)

1. Easy finding the funds and the support of the public initiatives from private capitals. The model defined the cooperation of at least one public entity with one or more private sector companies, the so called concessionaires.

2. The model involved a contract between two or more parties which limited the risk since it was distributed among a greater number of involved parties. The shared risk was economic, technical and operational while the profits from the project would be shared respectively to the companies involved based on their contribution.

3. It allowed various services and multiple roles to the parties involved.

4. It could achieve effective use of the resources, which was very essential to reduce costs.

5. This model guaranteed safety and sustainable financial base for the companies involved but also for the project as a whole.

6. The costs would be distributed in time among the users and not the constructors of the project. Another option based on the model was for the state to bear the costs and finally the group of companies. This project was covered by $33 \%$ from the private sector and $67 \%$ from public funds..

\section{Examination of the Business Model}

The model that was suggested by E. Sreedharan and his colleagues consists of different phases. Specifically in Phase I the Delhi Metro would include a fair sharing of costs, $40 \%$ from the state and $60 \%$ from borrowing. Specifically according to the present model the $38.78 \%$ would have to come from the state budget, $1.22 \%$ would be from the government in relation to the cost of the land and finally the remaining $60 \%$ would come from borrowing as mentioned above.

During the first phase, the loan would originate from two sources; the first source was the JBIC, which would give a loan at $1.3 \%$ per year, which would be available for a period of 30 years with a moratorium for 10 years. The other source was a domestic loan at $10 \%$ per year with a moratorium for 20 years (Anvuur, and Kumaraswamy,2007). 
In the end, the proposal that was promoted was to acquire a loan only from JBIC for both the phases I and II of the project. In the course because AEML, would not participate in the second phase, JBIC, gave loan only for the first phase of the project and the remaining costs would be covered by loans from the domestic market. The advantages and disadvantages of the model were as follows (Crowley and Karim, 1995):

\section{Advantages:}

1. The project would not be covered for at least the first phase of public funds, and this wouldn't burden the state, which would have the discretion to invest the money in other actions.

2. The project would evolve much faster which was necessary given the conditions and the undertaking of the Games that the city had to organize.

3. The cost of the project would be covered over time, which was easier for the state and its citizens in relation to its repayment.

Disadvantages:

1. The project would be covered by a loan so the state should yield profits from the Games in order to meet its obligations and avoid conveying the burden to the citizens.

2. The non-participation of AEML in the second phase was a disadvantage regarding the borrowing and at a level of homogeneity of the project during the second phase where another company would get involved.

3. Borrowing from the domestic market was unprofitable in terms of interest and repayment period so that phase II would have increased costs for the citizens.

\section{Results and Discussion}

Based on the model which was described previously, the cost for the construction of the project including land, construction of stations and their benefits would be covered by the government and the construction companies of the airport. The Operating and maintenance costs of the project would be covered by private companies and in this sense the construction of the project would be $70 \%, 30 \%$.

According to Burnett (2007) in projects of public interest where the state has the largest participation, the project becomes more alluring to prospective investors since they have more profit potential and development and have limited risk than other projects where the risk is shared (Burnett, 2007).At the same time these perspectives would be even more focused, in the event that the state gives further incentives to private companies supporting the work with percentages in profits, or integrating tax benefits.

Private companies have a unique opportunity based on the selected model to work with the government and proceed with the construction of a project enhancing their brand-name, without investing too much capital and having the ability to utilize it to their favor after the completion of the project. DMRC could use as an alternative model the public value model. Based on this the citizens are able to participate in the decision making process (Teicher, et all, 2006). According to this model, the government would win the trust of citizens and improve its transaction with them.

This procedure would make the citizens co-participants in the decision-making process, reduce responsibilities, reduce complaints while and at the same time it would also reduce the pressure on the budget of the country, where the citizens wouldn't let it be affected thus managing to reduce costs and achieve better value for money, and also less risk since it would be shared with the companies (Teicher, et all 2006). Along with this model the needs of the citizens would have been considered and perceived regarding the structure that the project should have, and this would make the project be constructed according to the citizens' own expectations, leading them to accept in the future without objection to pay higher taxes, which would easily reduce future public debt.

Potential reactions from the part of the citizens and future customers would assist the State to investigate more the elements that would characterize the project and improve its structure and functionality. This model compared to the selected one, reduces the risks for the state and transforms citizens into involved stakeholders, which is not the case now, while it would force them based on their decisions to support the project more through the payment of higher taxes. 


\section{Conclusion}

Property development rights in specific locations point alongside the subway line and where the stations would be positioned should be combined with the city's transportation system and in due time making the project more viable and efficient. Nevertheless, the above suggestion depends on the availability of state land properties alongside the subway's line. Additionally, such a prospective also relies on the public demand for commercial real estate development in the different city areas which is often considered as an ability to finance the expenditure of capital.In view of the fact that in order to proceed with project development the covering of the capital expenditure is regarded as one of the most important and direct requirements, the real estate development could accept a disproportionate weight age.

However, the transportation project of the city is important not to become highly dependent on the development of property since this perspective could dissociate the centre of attention from the central part of the project. For this purpose the project should have the appropriate safeguards that would guarantee and protect the primary goal of the whole project which is the urban transportation. Furthermore, if the project ends up in strong dependence with property development, this entails an additional risk for the government since they would more likely fail to address properly the subject of the public transportation holistically since it will not take into consideration the potentials that could arise from several other specific implementations. Nevertheless, the economic activity is bound to be increased alongside the subway line which is considered as a significant advantage of the project and of course this will also raise the land value of the properties that are located near the stations that would be built. A proportion of this value could be captured in many ways in order to finance the project (Hodge, and Greve, 2007).

\section{References}

- Abou-bakr, A (2013), Managing Disasters Through Public-Private Partnerships, Georgetown University Press.

- Anvuur, AM and Kumaraswamy, MM (2007) Conceptual model of partnering and alliancing. Journal of Construction Engineering and Management, Vol.133, No.3 pp. 225-234 Crossref

- Burnett, M.(2007) "PPP - A decision maker's guide", European Institute of Public Administration

- Grimsey, D., and Mervyn, K. L.(2005) The Economics of Public Private Partnerships, Edward Elgar Publishing, Cheltenham, U.K., 2005, p. xv. Crossref

- Hodge, G. and Greve, C. (2007) Public-private partnerships: An international performance review. Public Administration Review, Vol.67, No.3, pp 545-58. $\underline{\text { Crossref }}$

- Larry G. Crowley and Karim, Md. A.(1995) “Conceptual Model of Partnering," Journal of Management and Engineering, Vol.11, No.5, pp. 33-39 Crossref

- Teicher, J., Alam, Q., A. an d Van Gramberg, B. (2006) Managing trust and relationships in PPPs: Some Australian experiences. International Review of Administrative Science,Vol.72, No.1, pp 85-100 Crossref 